\title{
Preharvest Treatments by Spraying Bioinsect and Moringa Extract on Fruit Fly and Improving Quality of Plum 'Santa Rosa' Cv. Fruits During Cold Storage. Anas A. Ahmed ${ }^{1}$ and Naglaa M. A. Yassin ${ }^{2}$ \\ ${ }^{1}$ Plant protection inst.,Agric.Res.Centre., Station, Sabahia., A.R.C. Giza Egypt. \\ ${ }^{2}$ Hort. Res. Station, Sabahia, Alex., Hort. Res. In., A.R.C. Giza Egypt.
}

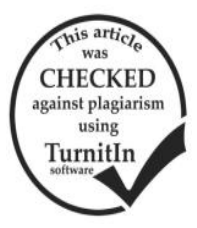

\section{ABSTRACT}

This experiment was carried out during 2015 and 2016 seasons on plum "Santa rosa"cv. fruits to study the effect of spray of three bioinsect $(100,150,200 \mathrm{~g} / 1001$ water $)$ and moringa extract $(100,150,200 \mathrm{~g} / 1001$ water $)$ at preharvest on quality of fruits during postharvest of plum fruits. Stored fruits at $0-2 \mathrm{c}^{0}$ and RH.90-95\%. Weight loss, decay, titratable acidity ,ssc and anthocyanin content were determined .Fruits treated in preharvest results showed that bioinsect $(150 \mathrm{~g} / \mathrm{l})$ were highest compatibility than all treatments. The advancing of cold storage periods weight loss, decay, tss $\%$ and anthocyanin content increasing, while titratable acidity \% decreasing during storage periods. Results indicated that fruits were treated with moringa extract $(100,200 \mathrm{~g} / \mathrm{l})$ had lower significant of weight loss, decay, titratable acidity and anthocyanin, while fruits were treated with bioinsect (100) had higher tss\% during storage period in both seasons.

Keywords : plum, bioinsect, Moringa, fruit fly,

\section{INTRODUCTION}

Plum "santa rosa "(prunus salicina) has been abandoned by many commercial growers due to its susceptibility to plum leaf scald and other bacterial diseases. Additional diseases and insects can affect plum trees as well, including scales,borers,mites, aphids, leaf spots and rots, Michelle(2008). The med flies Ceratitas capitata (Wied.) is considered the most seriously widespread insect-pest for fruits of many hosts in several countries (CIE,1988).This insect attacks about 400 hosts of fruits and vegetables reducing both quantity and quality of yield (White and Elson-Harris, 1992). For controlling C.capitata , many authors tried different control methods such as post-harvest treatments ,biological control agents ,sterile male technique, cultural practices, mass trapping and chemical control applications. Chemical control methods for med flies rely mainly on insecticidal application against both adult stage (as poison -bait sprat or as contact insecticides) and full grown larval or pupal stages (as contact toxicants) (Awad\&Hanafy ,2002; Hanafy ,2003; Elsherief 2009 and Ahmed et al.,2010).

Plant extracts are being used to manufacture natural are bioinsecticides which are environmental friendly and do not have any toxic effects on plants and soil. More ever they possess fungicidal and insecticidal properties. Various extracts such as neam leaf extract castor oil and neem oil on citrus fruits and moringa extract. Was best in retaining most of biochemical characteristics such as tss, acidity,pectin and ascorbic acid content and plant extracts increase the shelf life of the fruits and vegetables by reducing the fungal and bacterial spoilage during storage.

The aim of the present work was to study the effect of bioinsect and moringa extract on fruit fly and improving quality of "Santa rosa" plum fruits.

\section{MATERIALS AND METHODS}

The investigation was carried out during 2015 and 2016 seasons on plum 'Santa Rosa' cv. fruits (prunus domestica. ) .Fruits were harvested from plants grown in It harvest at Maruot ,Alexandria Governorate harvested at mature stage. Fruits were immediately transported to the laboratory of handling and postharvest at sabahia station Alexandria, horticulture researchers of Giza, Egypt. Then fruits divided into eight parts each part contained six fruits. Plum fruits were received the following treatments at preharvest as follows:
1. At preharvest three concentration of bioinsect (bioinsect local $32 * 106 / \mathrm{ml} \mathrm{g}$ fungi spores ) were used $200 \mathrm{~g} / \mathrm{l}$, $150 \mathrm{~g} / 1$ and $100 \mathrm{~g} / 1$ sprays solutions on the fruits.

2. Three concentration of moringa extract $200 \mathrm{~g} / 1,150 \mathrm{~g} / \mathrm{l}$ and $100 \mathrm{~g} / \mathrm{l}$ the rate of the solutions on the fruits.

3. Malathion .

4. Fruits untreated (control fruits).

Tested were inspected after 3,5 and 7days of hanging. In postharvest sound fruits were selected on the basis of uniformity of size and color. Sound selected fruits were divided into six groups for each treatment following as:

1. Fruits sprayed with moringa $200 \mathrm{~g} / 1$

2. Fruits sprayed with moringa $100 \mathrm{~g} / 1$

3. Fruits sprayed with bioinsect $200 \mathrm{~g} / \mathrm{l}$

4. Fruits sprayed with bioinsect $100 \mathrm{~g} / \mathrm{l}$

5. Malthion.

6. Fruits untreated.

All treatments stored at $0-2 \mathrm{C}^{\circ}$ and RH. (90$95 \%$ ). The changes in physical and chemical properties of fruits were followed up each seven days interval through the experimental period as following :

Physical characteristics:

Weight loss (\%):

It was calculated according to the following equation:

Weight loss $(\%)=[($ Initial weight - weight at sampling date $) /$ Initial weight] $x \mathbf{1 0 0}$

Three fruits were labeled in every replicate and initially weighed to calculate the fruits weight loss percent during the cold storage in relation to its original weight.

Determining the infestation of fruits by peach flies:

Is known by the number of holes in the fruit itself. the more number of holes the more infestation percentage as the number of eggs increase .

\section{Decay Percentage:}

Incidence and external fruit appearance was estimated according to the following equation:

Decay $(\%)=($ Number of decayed slices $/$ Number of initial slices $) \times 100$

Chemical properties

Soluble solids content (SSC):

The obtained juice was used to determine the percentage of soluble solids content (SSC) by the use of a hand refractometer according to Chen. and Mellenthin (1981) Titratable acidity (\%):

Total acidity was determined by titrating $5 \mathrm{ml}$ of the extracted juice against $0.1 \mathrm{~N}$ of $\mathrm{NaOH}$ using phenolphethalin indicator, titratable acidity was expressed as percentage of citric acid (g citric acid/100ml juice) according to (AOAC, 2005) 


\section{Anthocyanin content:}

Anthocyanin of peel was determined following the method of Fueki and Francis (1968). Three samples of 50g peel of each treatments were extracted in $100 \mathrm{ml}$ mixture of ethanol and HCL $(85: 15)$. Five milliliters of above extraction centrifugated for $10 \mathrm{~min}$ were measured spectrophotometrically at $535 \mathrm{~nm}$ and anthocyanin content was calculated as $\mathrm{mg} / 100 \mathrm{~g}$ sample.

\section{Statistical Analysis:}

The experimental design was RCBD with three replicates, and all the obtained data were statistically analyzed according to Snedecor and Cochran (1990). The individual comparisons were carried out by using the least significant difference (LSD) according to SAS Institute (1985). The experiment was distributed in split -split design and the means were compared by L.S.D at 0.05 according to Steel and Torrie(1980).

\section{RESULTS}

\section{Preharvest:}

Effect (Evaluated) of Different Compounds some materials neutral product ; fungicide ; insecticide and control on medfly Ceratitas capitata

The results in Table (1), indicated that there were highly significant between the compounds used. The means can be arranged in descending order according to control the med flies Ceratitas capitata (Wied.) on Bullace orchards as follows , Malathion (19.03 flies), Moringa (39.15 flies) and Bioinsect (59.89 flies)while control was (141.89 flies), respectively .El-Shahaat et al. (1993).

Table 1. Effect of different compounds some materials neutral product ; fungicide ; insecticide and control on medfly Ceratitas capitata

\begin{tabular}{|c|c|c|c|c|c|}
\hline \multirow{2}{*}{$\begin{array}{l}\text { Different } \\
\text { Compounds** }\end{array}$} & \multicolumn{4}{|c|}{$\begin{array}{l}\text { No. of flies (med flies)in traps* } \\
\text {,periods after hanging traps }\end{array}$} & \multirow{2}{*}{$\begin{array}{l}\text { General } \\
\text { mean }\end{array}$} \\
\hline & $\begin{array}{l}\text { Concentratio } \\
\text { n }\end{array}$ & 3days & 5days & 7 days & \\
\hline \multirow{4}{*}{ Malathion } & 100 & 9.00 & 10.00 & 12.00 & 10.33 \\
\hline & 150 & 13.33 & 16.00 & 17.00 & 15.44 \\
\hline & 200 & 27.00 & 32.00 & 35.00 & 31.33 \\
\hline & $\begin{array}{l}\text { General } \\
\text { mean }\end{array}$ & 16.44 & 19.33 & 21.33 & $19.03 \mathrm{de}$ \\
\hline \multirow{4}{*}{ Morenga } & 100 & 17.00 & 21.00 & 26.00 & 21.33 \\
\hline & 150 & 34.00 & 44.00 & 50.00 & 42.67 \\
\hline & 200 & 45.00 & 55.67 & 59.67 & 53.45 \\
\hline & $\begin{array}{l}\text { General } \\
\text { mean }\end{array}$ & 32.00 & 40.22 & 45.22 & $39.15 \mathrm{c}$ \\
\hline \multirow{4}{*}{ Bioinsect } & 100 & 56.00 & 58.00 & 60.00 & 58.00 \\
\hline & 150 & 57.00 & 58.67 & 61.33 & 59.00 \\
\hline & 200 & 58.00 & 61.33 & 63.33 & 60.89 \\
\hline & $\begin{array}{l}\text { General } \\
\text { mean }\end{array}$ & 57.00 & 59.33 & 61.55 & $59.29 b$ \\
\hline \multirow{5}{*}{ Control } & 100 & 94.33 & 97.00 & 100.67 & 97.33 \\
\hline & 150 & 142.00 & 142.67 & 155.33 & 146.67 \\
\hline & 200 & 193.00 & 195.00 & 197.00 & 195.00 \\
\hline & $\begin{array}{l}\text { General } \\
\text { mean }\end{array}$ & 143.11 & 144.89 & 151.00 & $146.33 \mathrm{a}$ \\
\hline & General m & 2.14 & $05.94 b$ & $09.18 a$ & \\
\hline
\end{tabular}

L.S.D. 0.05 for periods $=0.69 \quad$ L.S.D. 0.05 for materials $=0.39$ * Mean of three replicates

**Different Compounds (insecticide, natural product, fungicide and control)

\section{Different periods}

It may be clear in the same Table that the highest effect was accorded after 3 days (62.14 flies) while the lowest effect was (69.78 flies) after 7 days, Hanafy and Awad (2002).
Three concentrations from different compounds were used in filed on med flies Ceratitas capitata:

The results summarized in Table (2) showed that the efficiency of (100) concentration was (46.75 flies) followed by (150) concentration (65.95 flies) and (200) concentration was (85.17 flies) respectively, Saafan (2000).

Table 2 . Three concentrations from different compounds were used in filed on med flies Ceratitas capitata

\begin{tabular}{lcccc}
\hline Different & \multicolumn{3}{c}{ Concentration } & $\begin{array}{c}\text { General } \\
\text { mean }\end{array}$ \\
\cline { 2 - 4 } Compounds & $\mathbf{1 0 0}$ & $\mathbf{1 5 0}$ & $\mathbf{2 0 0}$ & 19.44 \\
Malathion & 10.33 & 15.43 & 31.33 & $19.03 \mathrm{de}$ \\
Morenga & 21.33 & 42.67 & 53.45 & $39.15 \mathrm{c}$ \\
Bioinsect & 58.00 & 59.00 & 60.89 & $59.29 \mathrm{~b}$ \\
Control & 97.33 & 146.67 & 195.00 & $146.33 \mathrm{a}$ \\
General mean & $46.75 \mathrm{c}$ & $65.95 \mathrm{~b}$ & $85.17 \mathrm{a}$ & \\
\hline L.S.D. 0.05 for periods $=0.72$ & \multicolumn{2}{c}{ L.S.D. 0.05 for materials $=0.39$} \\
\hline
\end{tabular}

\section{In postharvest:}

Physical properties:

Weight loss \%:

Data presented in Table (3) showed that ,the effect of bioinsect and moringa extract on weight loss of plum 'Santa rosa' cv. fruits during 2015 and 2016 seasons Weight loss percentage was gradually increased toward the storage periods with significant differences among all storage period in both seasons of study. The weight loss attributed mainly to water loss from the fruit tissues and partially for the respiration. The later result agree with those reported by El Saedy and El nagger( 2005).

Table 3. The effect of bio insect and moringa extract on weight loss \% of plum 'Santa Rosa' cv. fruits during cold storage at0-2 $\mathrm{c}^{0}$ during seasons 2015-2016.

\begin{tabular}{lccccc}
\hline \multicolumn{7}{c}{ Storage periods days 2015 } \\
\hline Treatments & $\mathbf{0}$ & $\mathbf{7}$ & $\mathbf{1 4}$ & $\mathbf{2 1}$ & Means \\
\hline Moringa100ml/1 & 0.00 & 7.83 & 9.14 & 10.94 & $6.97 \mathrm{c}$ \\
Moringa 200ml/1 & 0.00 & 7.76 & 9.16 & 10.76 & $6.93 \mathrm{c}$ \\
Bioinsect $100 \mathrm{ml} / 1$ & 0.00 & 8.12 & 11.04 & 12.99 & $8.03 \mathrm{~b}$ \\
Bioinsect 200ml/1 & 0.00 & 8.08 & 10.91 & 15.36 & $8.58 \mathrm{ab}$ \\
Malthion & 0.00 & 7.81 & 11.11 & 16.13 & $8.76 \mathrm{ab}$ \\
Control & 0.00 & 8.16 & 12.14 & 15.29 & $8.95 \mathrm{a}$ \\
Means & $0 \mathrm{~d}$ & $7.96 \mathrm{c}$ & $10.62 \mathrm{~b}$ & $13.58 \mathrm{a}$ & \\
\hline \multicolumn{5}{c}{ Storage periods days 2016 } & \\
\hline Treatments & $\mathbf{0}$ & 7 & $\mathbf{1 4}$ & $\mathbf{2 1}$ & Means \\
\hline Moringa $100 \mathrm{ml} / 1$ & 0.00 & 6.13 & 8.73 & 10.47 & $6.33 \mathrm{c}$ \\
Moringa 200ml/1 & 0.00 & 7.3 & 8.9 & 7.7 & $5.99 \mathrm{c}$ \\
Bioinsect 100ml/1 & 0.00 & 4.93 & 7.67 & 11.08 & $5.92 \mathrm{c}$ \\
Bioinsect 200ml/1 & 0.00 & 6.83 & 8.71 & 11.63 & $6.79 \mathrm{c}$ \\
Malthion & 0.00 & 8.08 & 12.5 & 15.44 & $9.01 \mathrm{~b}$ \\
Control & 0.00 & 9.83 & 13.76 & 19.08 & $10.67 \mathrm{a}$ \\
Means & $0 \mathrm{~d}$ & $7.18 \mathrm{c}$ & $10.05 \mathrm{~b}$ & $12.57 \mathrm{a}$ &
\end{tabular}

\begin{tabular}{lrrr} 
Means & $0 \mathrm{~d}$ & $7.18 \mathrm{c}$ & $10.05 \mathrm{~b}$ \\
\hline L.S.D2015: $\mathrm{A}=0.904$ & $\mathrm{~B}=0.725$
\end{tabular}

L.S.D2016: $\mathrm{A}=1.24 \quad \mathrm{~B}=1.111$

Fruits were treated moringa extract $(100,200 \mathrm{ml} / \mathrm{l})$ reduced weight loss $\%$ than all treatments in the first season but fruits were treated moringa extract (100, $200 \mathrm{ml} / \mathrm{l})$ and fruits were treated bioinsect $(100,200 \mathrm{ml} / \mathrm{l})$ reduced weight loss \% than all treatments in the second season. These results agree with Ghassan (2013).on orange showed that there is a correlation between effectiveness of the extracts and activity against the brine shrimp nauplii using extracts plant.

Decay Percentage:

Data presented in Table (4) illustrated that the effect of bioinsect and moringa extract on decay \% of plum "Santa rosa" cv. fruits during 2015 and 2016 seasons decay $\%$ was gradually increased toward the storage periods with significant differences among all storage period in both seasons of study.) liu et al., (2002) on apricots and plums. 
In both seasons, it was noticed that fruits were un trearted was higher significantly compared with all treatments and fruits were treated with moringa (100, $200 \mathrm{ml} / \mathrm{l}$ ) recorded that the lowest percentage compared with all treatments. This result agree with Ghassan (2013) reported that the plant extract as alternative against the fungi.

Table 4. The effect of bioinsect and moringa extract on acidity \% of plum 'Santa Rosa' cv. fruits during cold storage at0-2 $\mathrm{c}^{0}$ during seasons 2015-2016.

\begin{tabular}{lccccc}
\hline \multicolumn{7}{c}{ Storage periods days 2015 } \\
\hline Treatments & $\mathbf{0}$ & $\mathbf{7}$ & $\mathbf{1 4}$ & $\mathbf{2 1}$ & Means \\
\hline Moringa100ml/1 & 0.70 & 0.75 & 0.64 & 0.45 & $0.64 \mathrm{a}$ \\
Moringa200ml/1 & 0.70 & 0.70 & 0.54 & 0.37 & $0.58 \mathrm{cb}$ \\
Bioinsect 100ml/1 & 0.70 & 0.71 & 0.64 & 0.31 & $0.59 \mathrm{~B}$ \\
Bioinsect 200ml/1 & 0.70 & 0.68 & 0.55 & 0.31 & $0.56 \mathrm{cb}$ \\
Malthion & 0.70 & 0.65 & 0.54 & 0.32 & $0.55 \mathrm{c}$ \\
Control & 0.70 & 0.67 & 0.50 & 0.33 & $0.55 \mathrm{C}$ \\
Means & $0.70 \mathrm{a}$ & $0.69 \mathrm{a}$ & $0.57 \mathrm{~b}$ & $0.35 \mathrm{c}$ \\
\hline \multicolumn{7}{c}{} \\
\hline Treatments & Storage periods days 2016 \\
Moringa $100 \mathrm{ml} / 1$ & 0.80 & 0.74 & 0.60 & 0.44 & $0.65 \mathrm{a}$ \\
Moringa200ml/1 & 0.80 & 0.73 & 0.54 & 0.40 & $0.62 \mathrm{a}$ \\
Bioinsect 100ml/1 & 0.80 & 0.65 & 0.56 & 0.33 & $0.58 \mathrm{a}$ \\
Bioinsect 200ml/1 & 0.80 & 0.63 & 0.53 & 0.36 & $0.59 \mathrm{a}$ \\
Malthion & 0.80 & 0.60 & 0.53 & 0.34 & $0.56 \mathrm{a}$ \\
Control & 0.80 & 0.61 & 0.51 & 0.35 & $0.56 \mathrm{a}$ \\
Means & $0.80 \mathrm{a}$ & $0.66 \mathrm{a}$ & $0.54 \mathrm{a}$ & $0.37 \mathrm{a}$ & \\
\hline L.S.D2015: $\mathrm{A}=$ & 0.033 & \multicolumn{7}{c}{$\mathrm{B}=0.023$} \\
L.S.D2016: A=5.73 & \multicolumn{7}{c}{$\mathrm{B}=4.260$} \\
\hline
\end{tabular}

\section{Chemical characteristics:}

Titratable acididty :

Data in Table (5) revealed that titratable acidity (TA\%) decreased with the progress in storage periods. All treatments decreased TA\% than the control, with significant differences between the treatments were obtained during storage periods at the most cases in the two seasons.

Table 5. The effect of bioinsect and moringa extract on total soluble solid (tss) \% of plum'Santa Rosa' cv. fruits during cold storage at0-2 $\mathrm{c}^{0}$ during seasons 20152016.

\begin{tabular}{|c|c|c|c|c|c|}
\hline \multicolumn{6}{|c|}{ Storage periods days 2015} \\
\hline Treatments & $\mathbf{0}$ & 7 & 14 & 21 & Means \\
\hline Moringa $100 \mathrm{ml} / 1$ & 13.5 & 14.16 & 15.16 & 16.5 & $14.83 \mathrm{abc}$ \\
\hline Moring $200 \mathrm{ml} / 1$ & 13.5 & 14.13 & 14.66 & 16.66 & $14.74 \mathrm{bc}$ \\
\hline Bioinsect $100 \mathrm{ml} / 1$ & 13.5 & 14.07 & 15.50 & 15.33 & $14.6 \mathrm{c}$ \\
\hline Bioinsect 200ml/1 & 13.5 & 14.33 & 15.5 & 16.16 & $14.87 \mathrm{abc}$ \\
\hline Malthion & 13.5 & 15.5 & 15.83 & 15.53 & $15.09 \mathrm{a}$ \\
\hline Control & 13.5 & 15.13 & 15.5 & 16.16 & $15.07 \mathrm{ab}$ \\
\hline Means & $13.5 \mathrm{~d}$ & $14.56 \mathrm{c}$ & $15.36 \mathrm{~b}$ & $16.06 \mathrm{a}$ & \\
\hline \multicolumn{6}{|c|}{ Storage periods days 2016} \\
\hline$\overline{\text { Treatments }}$ & $\mathbf{0}$ & 7 & 14 & 21 & Means \\
\hline Moringa $100 \mathrm{ml} / 1$ & 13 & 14.5 & 15.5 & 16.16 & $14.79 \mathrm{~cd}$ \\
\hline Moringa 200ml/1 & 13 & 14.33 & 15.16 & 16.16 & $14.67 \mathrm{~d}$ \\
\hline Bioinsect $100 \mathrm{ml} / 1$ & 13 & 15.16 & 16.30 & 16.70 & $15.29 \mathrm{a}$ \\
\hline Bioinsect 200ml/1 & 13 & 14.8 & 15.83 & 16.3 & $14.98 \mathrm{cb}$ \\
\hline Malthion & 13 & 15.66 & 15.83 & 16.33 & $15.21 \mathrm{ab}$ \\
\hline Control & 13 & 14.5 & 15 & 16.66 & $14.79 \mathrm{~d}$ \\
\hline Means & $13 \mathrm{~d}$ & $14.83 \mathrm{c}$ & $15.6 \mathrm{~b}$ & $16.38 \mathrm{a}$ & \\
\hline L.S.D2015: $A=$ & 0.349 & & $\mathrm{~B}=0.3$ & & \\
\hline L.S.D2016: $A=$ & .262 & & $B=0$. & & \\
\hline
\end{tabular}

$$
\text { Decrease in TA percentage with advanced of storage }
$$

periods which could be due to the increase of its consumption in respiration activities as an organic substrate.

In both seasons, recorded that fruits were treated with moringa $(100,200 \mathrm{ml} / \mathrm{l})$ and fruits were treated bioinsect $(200 \mathrm{ml} / \mathrm{l})$ were higher significantly compared with all treatments this result in line with Islam and Saiful (2012).

Soluble solids content (SSC \%) :
From the tabulated data in Table(6) it cleared that soluble solids content (SSC \%) of fruits gradually increased with the advance in cold storage. Significant differences between the treatments were obtained during storage periods at the most cases in the two seasons. These results agreed with Dilawar et al (2007) on persimmon. Increasing in $\mathrm{tss} \%$ during storage might be associated with the transformation of pectic substances, starch, hemicelluloses or other polysaccharides in soluble sugar also with dehydration of fruits. Nath.et,al.(2012).on mandarin

Fruits were treated with bioinsect $(100 \mathrm{ml} / \mathrm{l})$, fruits were treated with Malathion and fruits un treated (control) were higher significantly compared with all treatments in both seasons. There in line with Nath.et,al.(2012).on mandarin

Table 6. The effect of bioinsect and moringa extract on anthocyanin( $\mathrm{g} / 100 \mathrm{ml}$ ) of plum 'Santa Rosa' cv. fruits during cold storage at $0-2 \mathrm{c}^{0}$ during seasons 2015-2016.

\begin{tabular}{lccccc}
\hline \multicolumn{7}{c}{ Storage periods days 2015 } \\
\hline Treatments & $\mathbf{0}$ & $\mathbf{7}$ & $\mathbf{1 4}$ & $\mathbf{2 1}$ & Means \\
\hline Moringa100ml/1 & 1.3 & 1.21 & 1.37 & 1.46 & $1.34 \mathrm{~b}$ \\
Moringa200ml/1 & 1.30 & 1.12 & 1.24 & 1.36 & $1.26 \mathrm{c}$ \\
Bioinsect 100ml/1 & 1.3 & 1.28 & 1.39 & 1.45 & $1.36 \mathrm{ab}$ \\
Bioinsect 200ml/1 & 1.3 & 1.28 & 1.51 & 1.55 & $1.41 \mathrm{a}$ \\
Malthion & 1.3 & 1.3 & 1.34 & 1.5 & $1.36 \mathrm{ab}$ \\
Control & 1.3 & 1.32 & 1.36 & 1.47 & $1.37 \mathrm{ab}$ \\
Means & $1.3 \mathrm{c}$ & $1.25 \mathrm{~d}$ & $1.37 \mathrm{~b}$ & $1.47 \mathrm{a}$ & \\
\hline \multicolumn{5}{c}{ Storage periods days 2016 } \\
Treatments & $\mathbf{0}$ & $\mathbf{7}$ & $\mathbf{1 4}$ & $\mathbf{2 1}$ & Means \\
\hline Moringa 100ml/1 & 0.9 & 1.32 & 1.43 & 1.61 & $1.32 \mathrm{cb}$ \\
Moringa 200ml/1 & 0.9 & 1.10 & 1.27 & 1.52 & $1.2 \mathrm{~d}$ \\
Bioinsect 100ml/1 & 0.9 & 1.37 & 1.41 & 1.64 & $1.33 \mathrm{~b}$ \\
Bioinsect 200ml/1 & 0.9 & 1.43 & 1.53 & 1.67 & $1.39 \mathrm{a}$ \\
Malthion & 0.9 & 1.31 & 1.4 & 1.52 & $1.29 \mathrm{c}$ \\
Control & 0.9 & 1.21 & 1.27 & 1.37 & $1.19 \mathrm{~d}$ \\
Means & $0.9 \mathrm{~d}$ & $1.29 \mathrm{c}$ & $1.39 \mathrm{~b}$ & $1.55 \mathrm{a}$ & \\
\hline L.S.D2015: $\mathrm{A}=0.074$ & \multicolumn{5}{c}{$\mathrm{B}=0.0415$} \\
L.S.D2016: A=0.042 & $\mathrm{B}=0.0224$ \\
\hline
\end{tabular}

\section{Anthocyanin contents:}

Results presented in Tables (7) showed that the effect of moringa extract and bioinsect on anthocyanin contents of plum "Santa rosa" cv. fruits during 2015 and 2016 seasons. Significant differences between the treatments were obtained during storage periods in both seasons. anthocyanin content gradually increased with the advanced in cold storage. (Holcroft et al.,1998). That was correlated with the activity of the enzymes of the anthocyanin biosynthetic pathway. Fruits were treated with moringa $(200 \mathrm{ml} / \mathrm{l})$ were lowest significantly compared with all treatments in both seasons. Were in line Brigita. et.al,(2005).reported that low anthocyanin due to its low content of polyphenols.

Table 7. The effect of bioinsect and moringa extract on decay $\%$ of plum 'Santa Rosa' cv. fruits during cold storage at0-2 $\mathrm{c}^{\mathrm{0}}$ during seasons 2015-2016. Storage periods days 2015

\begin{tabular}{lccccc}
\hline \multicolumn{7}{c}{ Sreatments } & $\mathbf{0}$ & $\mathbf{7}$ & $\mathbf{1 4}$ & $\mathbf{2 1}$ & Means \\
\hline Moringa100ml/1 & 0.00 & 0.66 & 1 & 3 & $1.17 \mathrm{c}$ \\
Moringa200ml/1 & 0.00 & 1 & 1 & 4 & $1.5 \mathrm{cb}$ \\
Bioinsect $100 \mathrm{ml} / 1$ & 0.00 & 0.66 & 1.33 & 2.33 & $1.08 \mathrm{c}$ \\
Bioinsect $200 \mathrm{ml} / 1$ & 0.00 & 0.66 & 1.33 & 6 & $2.00 \mathrm{cb}$ \\
Malthion & 0.00 & 2 & 2 & 5 & $2.25 \mathrm{~b}$ \\
Control & 0.00 & 4 & 5.33 & 6 & $3.83 \mathrm{a}$ \\
Means & $0 \mathrm{~d}$ & $1.5 \mathrm{c}$ & $2 \mathrm{~b}$ & $4.38 \mathrm{a}$ & \\
\hline \multicolumn{7}{c}{ Storage } & $\mathbf{0}$ & $\mathbf{7}$ & $\mathbf{1 4}$ & $\mathbf{2 1}$ & Means \\
\hline Treatments & $\mathbf{0}$ & $\mathbf{1 4}$ & \\
\hline Moringa100ml/1 & 0.00 & 1.33 & 2.33 & 4.33 & $2.00 \mathrm{bc}$ \\
Moringa200ml $/ 1$ & 0.00 & 2 & 3 & 3.66 & $2.17 \mathrm{~b}$ \\
\hline
\end{tabular}




\begin{tabular}{lccccc}
\hline Bioinsect $100 \mathrm{ml} / 1$ & 0.00 & 1.33 & 2.33 & 0 & $1.5 \mathrm{c}$ \\
Bioinsect 200ml/1 & 0.00 & 2.33 & 3.33 & 4.33 & $2.5 \mathrm{~b}$ \\
Malthion & 0.00 & 2.33 & 3.33 & 4.33 & $2.5 \mathrm{~b}$ \\
Control & 0.00 & 5.33 & 7.33 & 10.33 & $5.75 \mathrm{a}$ \\
Means & $0.00 \mathrm{~d}$ & $2.44 \mathrm{c}$ & $3.61 \mathrm{~b}$ & $4.89 \mathrm{a}$ & \\
\hline L.S.D2015: $\mathrm{A}=1.068$ & $\mathrm{~B}=0.424$ \\
L.S.D2016: $\mathrm{A}=0.585$ & $\mathrm{~B}=0.471$ \\
\hline
\end{tabular}

\section{REFERENCES}

Ahmed Anas A.; A.M.Z. Mosallam and A.H.A. Hanafy (2010): Efficiency of natural compounds as insecticides for the Mediterranean fruit fly Ceratitas capitata (Wied.)(Diptera,Tephritidae). Egypt. J. of Appl. Sci.25 (6B):191-199.

AOAC (2005). Official Methods of Analysis. $18^{\text {th }}$ ed. Association of Official Analysis Chemists. Washington, D.C., USA

Awad,A.I. and A.H. Hanafy (2002):Field evaluation of complete coverage and partial bait sprays with some recommended insecticides wit food and sex attractant for control the the Mediterranean fruit fly Ceratitas capitata (Wied.) in Guava orchards in Alexandria Governorate. $2^{\text {nd }}$ Inter.Conf. Plant Prot. Res, Inst., Cairo, Egypt, 21-24 December : 664-670.

Brigita.L.M. Prosek, and Alenka.G.,(2005).Comparison of extracts prepared from plant by products using different solvents and extraction time.journal of food engineering vol.71(2):214-222.

Chen, P.M. and W.M. Mellenthin (1981). Effects of harvest date on ripening capacity and post-harvest Life of d'Anjou pears. J. Amer .Soc. Hort. Sci., 106 (1): $38-42$

CIE (1988): Ceratitas capitata (Wied.) (Diptera, Tephritidae) .CAB International Institute of Entomology, Distribution Maps of Pests ,Series A (Agricultural ),(1), revised, 1-3. CAB International London.

Dilawar ,K,A.R,Khan.S.Bibi,S.Ali,and I,A.Khalil (2007). Storage stability of persimmon fruits (Diospyros Kaki) stored in different packaging materials. Journal of agricultural and biological science vol 2 no 2.

El-Saedy, R.M. and N.I. El-Naggar (2005). Retardation of chilling injury symptoms and reducing quality loss of Catcus pear fruits during cold storage by heat treatments. Alex. Sci. Jour., $30: 3$.

El-Shahaat M.S., Hanafy A.H. and El-Okda M.Kh. (1993): Preparing a new insect food attractant and efficiency of its toxic bait spray against the Mediterranean fruit fly Ceratitas capitata (Wied.) in Guava orchards, Alex. Sci. Exch., Vol. 14,No. 2.

Elsherief (2009). The efficiency of natural compounds as insecticides against peach fruit fly Bacterrocera zonata (saund).J.agric.sci. Mansoura unvi.,34(1): 497-507

Fueki,T. and F.J. Francis (1968). Quantitative method for anthocyanin .Extraction and determination of total anthocyanin in cranberries.J .Food sci.33:72-77.

GhassanF.AL-Samarrai,H.S, and Malaysia P. (2013). Extract some plants on controlling green mold of orange and on postharvest quality parameters. World applied sciences journal 22(4);564-570.

Hanafy ,A.H. and A.I. Awad (2002):Toxic bait spray as an effective

Hanafy ,A.H.(2003):Field evaluation of food attractants and its toxic bait spray against the Med fly, Ceratitas capitata (Wied.)on guava and citrus trees. Egypt. J.Appl. Sci.,18(4B): 624-634

Holcroft, D.M.,M.I. Gill and A.A.Kader(1998). Effect of carbon dioxide on anthocyanins, phenylalanine ammonialyase and glucosyl transferase in the arils of stored pomegranates.J.Amer.soc.hort sci.123(1):136-140.

Islam,MD.Saiful (2012) .Effects of plants extracts on the extension of shelf life of papay without affecting the postharvest quality of fruits.http://hdl.handle.net.

Liu, W.T., Chul C.L. and zhou T. (2002).Thymol and acetic acid vapors Reduce postharvest Brown Rot of Apricots and plums. Hort science vol 37 no (1) page $151-156$

Michelle M.,'(2008 ) Santa rosa plum tree information www.homeguides.sfgate.com.

Nath.A.K.Barman.S.Chandra,P.Baiswar (2012).Effect of plant extracts on quality of Khasi mandarin (Citrus reticulate Blanco) fruits during ambient storage. Food and bioprocess technology vol.6,issue $2 \mathrm{pp}$ 470-474.

Saafan M.H.(2000): Integrated control of Ceratitas capitata (Wied.)in apricot orchards in Egypt-Alex. .J. Agric. Ros., 78 (1),109-120.

SAS (1985). SAS uses 'guide statistics for personal computers version $5^{\text {th }} \mathrm{Ed}$. SAS Inst. Cary $\mathrm{N}$ Co.

Snedecor, W and A. Cochran (1990): Statistical Methods. The Iowa State Univ. press, Ames, Iowa, USA.

Steel,R.G.D and J.H. Torri (1980):Principals and procedures of statistics.A biometrical approach. $2^{\text {nd }}$ MC Grow-Hill kogakusha ltd.,p.633.

Steel,R.G.D. and I.H. Torri (1980):Principles and procedures of statistics, a Biometrical Approach. $2^{\text {nd }}$ ED By McGrae -Hill International Book Company Singapore.

White,I.M. and M.M. Elson-Harris (1992): Fruit flies of economic significance : their identification and bionomics $\mathrm{CAB}$ international, London, pp601.

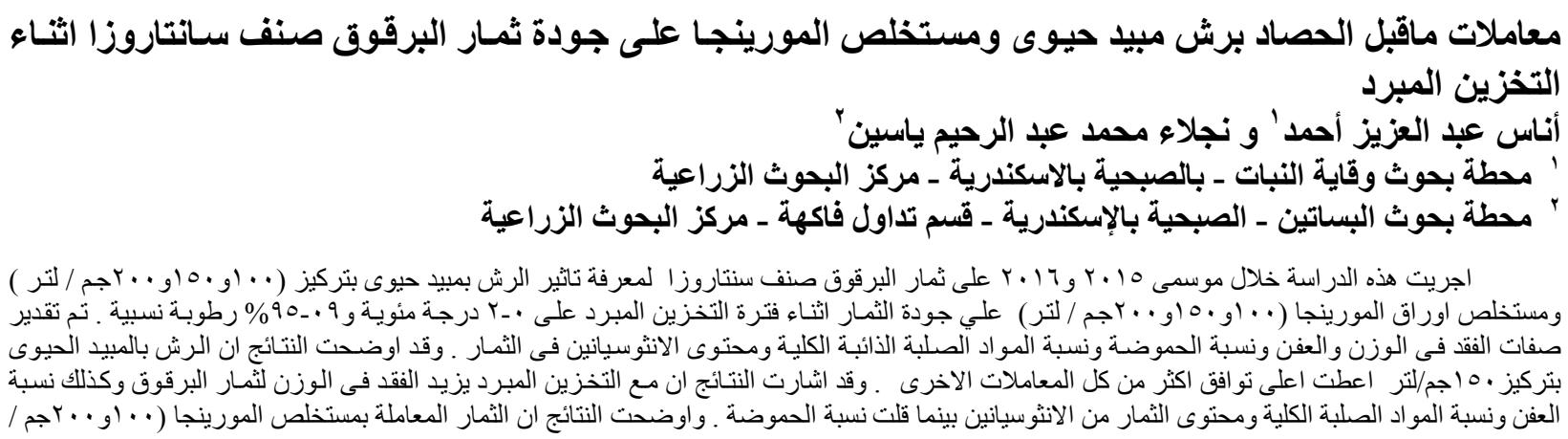


J. Plant Prot. and Path., Mansoura Univ., Vol.7(12), December, 2016

التجر ) اعطت . اقل نسبة فقد فى الوزن والعفن والانثوسيانين بينما الثمار المعاملة بالمبيد الحيوى ( • (جم/لتر) كانت اعلي فى نسبة المو اد الصلبة الكلية خلال موسمى 